\title{
Review Article Social Justice Education and the Role of Museums
}

\author{
Amy K. Levin
}

Gonzales, Elena, Exhibitions for Social Justice. Abingdon, Oxon.: Routledge, 2020, hardback $£ 120$, paperback $£ 34.99$, ebook $£ 31.49,194$ pp.

Kostache, Irina D., and Clare Kunny, eds. Academics, Artists, and Museums:

21st-Century Partnerships. Abingdon, Oxon.: Routledge, 2019, hardback £120, paperback $£ 36.99$, ebook $£ 40.49,204$ pp.

\section{Quinn, Therese, about Museums, Culture, and Justice to Explore in Your Classroom, New York: Teachers College Press, 2020, hardback \$75, paperback \$24.95, ebook \$19.96, 95 pp. [Amazon UK £81.95, £27.50, £18.68]}

These three books engage with museums and their role in education, with particular emphasis on social justice learning. Elena Gonzales's Exhibitions for Social Justice examines how institutions can best build empathy in visitors and then turn that empathy into action; she provides concrete advice, especially for practitioners. In Therese Quinn's about Museums, Culture, and Justice to Explore in Your Classroom, the primary focus is on questions and activities that school teachers can adopt that will increase students' understanding of museums as social institutions embedded in structures of power. And finally, in Academics, Artists, and Museums: 21st-Century Partnerships, the spotlight is more on collaborations among practitioners, artists, and academics. The three texts are refreshingly brief and complement each other in helpful ways. Readers learn mostly about practices in the United States, but there are examples from countries as far apart as South Korea, Cameroon, and the Netherlands.

In Exhibitions for Social Justice, Gonzales begins broadly, addressing the purposes of museums and their educative functions. In her first chapter, she confronts the contradictions inherent in groups, because they are defined both by inclusion and exclusion. In this context, she argues for the importance of practising welcoming and hospitality. She also shares the common viewpoint that individual stories are essential in building empathy but recognizes that 'they privilege the power of the individual, the upstander, so much that we don't learn about creating institutional or systemic change' (36). For this, she argues (too repeatedly), it is necessary to build solidarity - among institutions, visitors, and communities.

The second chapter is most original, exploring physical experiences in the gallery and drawing on neurosciences in 'teaching content, building memories, building empathy, and, ultimately, inspiring action' (59). She is critical of exhibitions that are too immersive, because they can distress visitors; strategies to break up the intensity of such exhibits include the use of humour, rest stops, and clear narrative paths. Reference to Silke Arnold-de Simine's work on affect, memory, and empathy in museums would have deepened this analysis.

The third chapter discusses how museums can educate visitors for action. Given the difficulty in measuring empathy, much of Gonzales's assessment of these efforts remains qualitative rather than quantitative and involves speculation on the diffusive effects of individual responses. Pounding nails into a wall at an exhibit on Japanese internment in World War II may be visible action, but not terribly helpful.

Chapter Four provides a roundup of existing models for museums sharing authority with communities, including charts to assist in selecting which models to use and when 
(unfortunately, the tables were printed incorrectly, but the right versions can be found at http:// www.elenagonzales.org/buy-the-book.html). Examples drawn largely from Chicago-area institutions and the Eastern State Penitentiary Museum in Pennsylvania are intriguing, and Gonzales is open to discussing some failures. Many in the Dutch museum community would consider her assessment of the Rijksmuseum's decolonization efforts as overly positive.

The analysis of Holocaust exhibits can be troubling and contradictory. She criticizes one display because it 'reneges on the museum's commitment to hospitality' (67); she questions the use of artefacts and environments that are not authentic, but claims that experiences with them are authentic (68). These are difficult concepts. Following this train of thought as well as considering the practical suggestions would be useful to anyone in the field.

Therese Quinn's about Museums, Culture, and Justice to Explore in Your Classroom offers extraordinarily concrete advice for student activities, and its intended audience seems to be school teachers. Nevertheless, the proposed assignments may inspire museum educators who collaborate with schools. This practical focus does not obscure the fact that the text, which consists of ten chapters, is undergirded by deep knowledge of museums and current theory about their involvement with social justice. In ten short chapters - perhaps too many for such a brief book - she explores such themes as disability, decoloniality, gender, and intersectionality. Some projects relate to field trips, and many consist of alternative labelling. Case studies include Chicago-area museums such as the Chicago Children's Museum, but also cover institutions in other nations.

I found most inspiring an approach which I initially questioned. Many of the proposed activities do not involve actual museum visits, which may dismay museum staff. However, they do draw children and youth into deep, meta-level topics relating to museums' complicity in systems of power. In one instance, students consider the provenance of collections; in another, they study how museums are funded and by whom, making pie charts. In a third, students write text acknowledging the indigenous roots of their own 'territories'. The Western conception of science also comes in for scrutiny. Youth are not only encouraged to resist (traditional strategies of) curation but also to curate resistance, building community archives. This is genuine social activism for change. Such exercises may excite students as they see museums from multiple perspectives (one chapter even focuses on museum workers). Excitement also springs from the timeliness of the book, which refers to the on-going ICOM debate on definitions of museums.

The book possesses several drawbacks, however. While certain historical accounts support Quinn's points, they present supposition as fact. The most obvious is the assertion that the first museum was founded by a Babylonian woman, Bel Shalti-Nanna. Quinn could have made her point about the lack of credit given to Black women's achievements without presenting this as certainty. In another case, Quinn rightly presents the Louvre's roots in revolution, but glosses over the way much of the museum collection derived from colonial looting and plunder. At other times, Quinn's discussion seems unnecessarily idiosyncratic, as when she refers to her 'favorite' art teacher (25). Nevertheless, Quinn's book remains the most incisive of those under review.

Academics, Artists, and Museums: 21st-Century Partnerships takes the most conventional approach of the three books. Its emphasis is on higher education faculty, and many of the museums discussed are university galleries. Major institutions, such as the Metropolitan Museum of Art and the Getty, are also included, together with community institutions. Like Quinn's book, this collection is divided into very short sections - a dizzying five parts and fourteen chapters in fewer than 200 pages. While many of these chapters address questions of social justice, the latter is not the major focus of the book, which instead suggests methods for building visual literacy and critical thinking through involving students in art and interdisciplinary artistic collaborations. Sections focus on collaborations between museums and connected art schools; museum dialogues; interdisciplinary projects; audience engagement; and digital activities with artists. Inevitably, the contents of the sections overlap.

Several chapters deserve notice. A project in Korea which uses a museum to teach ESL (English as a Second Language) is intriguing. The author's difficulties in 'selling' the project to administrators and peers who prioritize other curricular concerns are shared by faculty around the world, rendering the discussion particularly useful. The interdisciplinary section 
includes an article on using museums to train medical students in observation, an increasingly popular practice. Catherine Carter Goebel begins on an excessively self-congratulatory note but moves quickly to details of a project in which first-year student essays related to museum exhibits are published in a reader for those in following years. Bimbola Akinbola's chapter complicates notions of truth in museums and promotes activism. Like Gonzales, Akinbola questions exhibits that are so immersive they are disturbing; here, too, a Holocaust museum is analyzed, but Akinbola considers the emotional weight of the displays to be an essential part of the institution's work.

Despite the strengths of these chapters, I found much of the book dry, and many of the activities are variations on the familiar educational practice of having students create exhibits, along with their accoutrements. Others involve artist interventions and college nights for students. The case studies may be interesting, but the nature of the collaborations is not particularly novel. For example, the use of museums in teaching ESL was the focus of a special issue of Museums and Social Issues in 2015. Moreover, because almost every chapter is written by those involved in the projects described, there are few opportunities for critical perspectives. A proper conclusion rather than an afterword, tying together thematics and stressing the importance of the topics to students motivated by social justice issues, would have strengthened the book's impact.

Readers will gain ideas about weaving museums and art throughout the university curriculum from the last book; they can learn practical strategies for using museums to develop social justice awareness in school-aged youth from Quinn; and they can access detailed information on practices for building social justice into exhibits from Gonzales. The ways in which these books complement each other will be helpful to educators and practitioners. At the same time, the books would be bolstered by additional evaluation or assessment of their claims as well as critical distance from the activities being described. Commitment to these practices is necessary to reduce conscious and unconscious bias as well as to maintain the public's trust in museums.

Amy K. Levin

Northern Illinois University, USA. 